\title{
Metafoorid, millega me töötame: kogumismetoodika kajastused Eesti Rahva Muuseumi soome-ugri ekspeditsioonipäevikutes aastatel 1975-1989
}

\section{Art Leete Piret Koosa}

Viimastel aastakümnetel on tekkinud kriitiline arutelu etnograafiliste kogumis- ja representatsiooniideoloogiate üle. ${ }^{1}$ Varasem muuseumikollektsioonide kujundamine põhines arusaamal, et etnograafidel on teaduslik autoriteet kogumaks kõike ning muuseum on esemetele parem varjupaik kui inimeste kodud. Tänapäeval on kogumispraktika muutunud, ent ikkagi püsib päevakorras küsimus sellest, kuidas käsitleda muuseumitöös varasemaid kollektsioone.

Põhiosa Eesti Rahva Muuseumi (ERM) soome-ugri kollektsioonist on kujunenud nõukogude ajal, 1960.-8o. aastatel. Massilise kogumistöö algatamine toimus Eesti NSV Teaduste Akadeemia Presiidiumi poolt 1957. aastal antud suuniste valguses, mis nägid ette muuseumite kollektsioonide suurendamist (Peterson 1960: 9-10). Esemete hulga kasv kogudes kujunes põhiliseks ekspeditsioonide edukuse mõõdikuks (Pärdi 1991: 566; Leete 1998b: 13). ERMi kõige intensiivsemal kogumistöö perioodil, 1980. aastate keskpaiku kinnitas muuseumi direktor Aleksei Peterson korduvalt, et esemete kogumine on esmatähtis. Kogumistöö oli „muutunud igasuguse muu töö aluseks [...],

\footnotetext{
1 Artikli valmimist on toetanud Tartu Ülikooli rahvusteaduste baasfinantseerimise projekt $\mathrm{nr} 19913$ „Soomeugrilased multietnilises ühiskonnas: kohtumine religioonide piiridel“ ja Hõimurahvaste programmi projekt nr 843/844 „Soome-ugri dialoogid: Nõukogude Eesti etnograafid hõimurahvaid uurimas (1944-1991)” .
} 
kõik muud tööd tulenevad sellest, on teisejärgulised“" (Peterson 1986: 23). Aasta varem ERMi teadusnõukogus esinedes kasutas Peterson sama lähenemisviisi õigustamiseks ERMi endise direktori Ferdinand Linnuse ${ }^{2}$ (1938: 135) väidet: „Teooriad tulevad ja lähevad, aga materjal jääb“ (ERM A, nõukogu protokollid n $1, \mathrm{~s} 531,1$ ).

Soome-ugri ekspeditsioonide taasalustamine (soome-ugri välitöid korraldati ka enne Teist maailmasõda ning sõja ajalgi, millele järgnes kahe kümnendi pikkune paus) asetus ERMis pikemaajalise strateegilise arengu raamistikku. Kogumise ekstensiivistamine 1950ndate lõpust võinuks toimuda ka ainult Eestis, muuseumilt ei nõutud elavnemist soome-ugri suunal. Soome-ugri etnograafia on olnud üheks ERMi põhimõtteliseks prioriteediks enam-vähem muuseumi rajamisest alates (Linnus 1970; Leete 1998b; Karm 2019). Soome-ugri etnograafia tähtsustamine paigutub ajalooliselt rahvusideoloogilisele taustale, huvi hõimurahvaste vastu sai alguse 19. sajandi II poolel rahvusliku ärkamisaja raamistikus. Nõukogude Liidu kontekstis kujunes hõimurahvastega tegelemine teatud vastukultuuri allikaks. (Arukask 2018; Jääts, Metslaid 2018: 122-123, 130-131; Karm 2019)

Ülevaatlikult on ERMi soome-ugri kogumistöö ajalugu, sh ka topograafilist arhiivi ehk päevikuid, oma artiklites käsitlenud Jüri Linnus (1970), Aleksei Peterson (1986) ja Toivo Sikka (1997). Konkreetsete rahvaste esemekogude sisu ja kujunemist on avanud Svetlana Karm (2002), Leete (1998a), Linnus (1982), Peterson (1982), Heiki Pärdi (1982) ja Vaike Reemann (1984). Välitööpäevikutele kui rikkalikku kultuuriloolist uurimismaterjali sisaldavatele allikatele on eraldi tähelepanu pööranud Pärdi (1995a; 1995b), Karm (2006) ja Marleen Nõmmela (2007a; 2007b).

Allikapublikatsioonidena on Svetlana Karmi koostatuna ilmunud Aleksei Petersoni udmurdi välitööde päevikud (Peterson 2006) ja Indrek Jäätsi koostatuna vepslaste seas toimunud välitööde päevikud (Jääts 2019a) ja põhjalikum päevikuid allikmaterjalina avav artikkel (Jääts 2019b; vt ka Jääts 2018). Seni ei ole muuseumi kogumistööd analüüsitud kontseptuaalsemal, abstraktsemal tasandil, mida selles artiklis välitööpäevikutele tuginedes teeme (meie analüüsi esialgset versiooni vt Koosa, Leete 2006).

Käesolevas artiklis keskendume ERMi soome-ugri välitööde päevikutes leiduvate esemekogumisega seotud metafooride välja selgitamisele ja tõlgendame ainest kogumise ajal levinud erialase diskursuse kontekstis. Kompaktsuse huvides piiritleme päevikud aastatega 1975-1989 ehk perioodiga, mil ERMi kogumistöö soome-ugri

2 Ferdinand Linnus (1895-1942), ERMi direktor aastatel 1928-1941. 
rahvaste seas oli kõige intensiivsem (vt Leete 1998b: 18-19). Nendel aastatel kogutud esemed moodustavad ligi 2/3 ERMi soome-ugri kogust (B-kogu). Soome-ugri välitööde päevikuid on ERMis kokku 139, neist 8 o kajastavad nimetatud ajavahemikul toimunud ekspeditsioone. Käesoleva uurimuse allikateks valisime nende hulgast 20 päevikut, lähtudes põhimõttest, et esindatud oleksid eeskätt need uurijad, kes kõnealusel perioodil soomeugrilaste juures rohkem välitöid tegid. Eeldatavalt kujundasid just need etnograafid välitööde kujutamise stiili põhijooned. Teisalt järgisime põhimõtet, et esindatud oleksid ka need välitöödel osalenud, kes sattusid soomeugrilaste juurde vaid korraks (üliõpilased-praktikandid) või kellel oli välitöödel mingi spetsiifiline roll (fotograaf, filmimees, kunstnik). Valikukriteeriumiks oli ka päeviku ilmekus, seega jäävad alaesindatuks asjalikult välitöid dokumenteerinud teadlased, kes oma päevikus metafoorseid väljendeid palju ei kasutanud. Etnograafiliste päevikutega seotud erialase diskursuse stiili kujundamisel jäävad need autorid pigem varju.

Soome-ugri etnograafia paigad ja praktikad on omavahel seotud metafoori kaudu. Päevikud on lugude jutustamise ootuspärane areen, sest tollal peeti seda väljaks, kust ei pidanud metafoore täpse teadusliku diskursuse nimel välja tõrjuma (vrd Sevilla Casas 2002: 5). Eri autorite päevikuid lugedes jäävad korduma teatud metafoorsed väljendid ja kujundid, mille kaudu oma tegevust kirjeldatakse. Etnograafid on pikka aega oma ülesandena näinud kohe-kohe lõplikult kaduva „traditsioonilise rahvakultuuri“ jäädvustamist. Oli ettekujutus „väärtuslikust“ teabest ja asjadest - see tähendas võimalikult vana, arhailist osa kultuurist. Traditsioonilise kultuuri kadumise kujundiga seostub selle „päästmise“ metafoor, etnograafide tööd on sageli tajutud ja kujutatud viimase hetke päästetöödena kultuuriväärtuste säilitamise nimel. (Maa)inimeste elu kaasajastumist, traditsiooniliste eluviiside teisenemist ja linnastumist on nende arusaamade taustal aga kujutatud teatava allakäiguna. Kõige jõulisemalt tuleb siin analüüsitavates päevikutes esile etnograafi töö iseloomustamine kauplemise, sõja ja saagi metafooridega.

Soome-ugri välitööde päevikud sisaldavad veel palju muudki materjali ega piirdu ääremärkustega esemekogumisele, kuid siinses artiklis on meie eesmärgiks uurida, kuidas ERMi etnograafid kasutasid metafoore, et kujundlikult dokumenteerida oma kogumistööd ja laiemat erialast ideoloogilist ja sotsiaalset konteksti. Oletame, et ERMi soomeugri välitööde päevikutest on metafooride kaudu võimalik tuvastada etnograafide suhtumist tollastesse professionaalsetesse praktikatesse, aga ka kultuuride kohtumisse, mis ekspeditsioonide käigus aset leidis. Analüüsides metafooride kasutamise erialaseid ja ühiskondlikke nüansse, püüame muuta etnograafilisi metafoore läbipaistvamateks. 


\section{Metafoorid ja etnograafia}

Arusaama metafoori heuristilise potentsiaali ulatusest tõid laiemale teadusväljale George Lakoff ja Mark Johnson oma 1980. aastal ilmunud monograafiaga „Metafoorid, mille järgi me elame“ (e k 2011). Metafoori sisuks on Lakoffi ja Johnsoni järgi „mõista ja kogeda üht liiki asja, sõnastades selle mingit teist liiki asja kaudu“ (2011: 37). Metafoor pole Lakoffi ja Johnsoni jaoks mitte lihtsalt abivahend tegelikkusest kaude kõnelemiseks, vaid igapäevase kogemuse ja põhiliste eksistentsiaalsete küsimuste ühenduslüliks. Metafoorid puudutavad Lakoffi ja Johnsoni järgi „inimliku olemise sügavaimaid küsimusi“, võimaldades seekaudu mõista ka argielu (Lakoff ja Johnson 1999: 118), sest argimõtlemine on suurel määral metafoorne (samas: 127-128). See igapäevase ja olemuslikult tähtsaima ühendamise funktsioon annab metafoorile jõu defineerimaks, mida me tajume reaalsusena (Lakoff ja Johnson 2011: 183).

Representatsioonikriisi lainel väideti, et metafoorid kujundavad etnograafia (Marcus 1998: 92) ja tõlgendamine on kogu uurimisprotsessi metafoor (Marcus ja Fischer 1999: 26). See tähendab püüdlust tuvastada sotsiaalseid korrelatsioone ning assotsiatiivseid põhjendusi, mis on kõige ilmsemad keelekasutuses (Marcus 1998: 92). Etnograafiline väli märgistatakse ja seda jälgitakse avastatud metafoorsete seoste kaudu (Marcus 1998: 93). Metafooride kasutamine võimaldab poeetilise meetodiga ületada lõhe kõikehõlmava inimliku kogemuse ja teadusliku etnograafilise teadmise vahel (Sevilla Casas 2002: 3).

Etnograafid on sunnitud oma tunnetusliku tegevuse eripära tõttu metafoore kasutama. Etnograafilist teadmist ei looda eeskätt teooriate, vaid pigem allegooriliste ja metafoorsete lugude kaudu (Clifford 1986: 98-100; Sevilla Casas 2002: 25-26). James Clifford täheldab, et etnograafilised välitööd on metafoorselt nii teaduslik „laboratoorium“ kui ka isiklik „üleminekuriitus“, korraga objektiivse ja isikliku tõe otsingu vorm (1986: 109).

Tõe seos metafooridega seisneb kirjeldatud kogemuse tähendusrikkas kokkupuutes eluga (Lakoff ja Johnson 2011: 211). Metafoorid toimivad juhul, kui nad toovad vahendatud kogemuse lugejale lähemale: „Metafoorid on oma põhiolemuselt mõistmise vahendid ja sellistena ei ole neil palju pistmist objektiivse reaalsusega.“ (samas: 222) Metafoorid sobivad välitööde kogemuse analüüsimiseks, kui neile esitada mitte liiga kõrgeid tunnetuslikke nõudmisi. Kõne all on etnograafide igapäevane kogemus, mitte suured eksistentsiaalsed väljakutsed. Seega ei pea me oma käsitluses tungima olemise ja tõe objektiivse reaalsuse küsimustesse. 
Christos Varvantakis ja Sevasti-Melissa Nolas leiavad, et metafoorid võimaldavad etnograafil ootamatutes olukordades loovalt reageerida, näha välitööde protsessi läbi mängulise ja eksperimentaalse prisma ning toetavad teadmise kujunemist. Lisaks metafooride osale üldise uurimisprotsessi käsitlemisel on neil ka spetsiifiliste olukordade mõtestamise funktsioon (Varvantakis ja Nolas 2019: 365-369).

Seega aitavad metafoorid esile tuua etnograafilist tõde komplitseeritud olukorras, kus teadlane satub tunnetuslikesse raskustesse oma kogemuse või mõistmise protsessi otsesõnu käsitlemisel. Samuti võivad metafoorid avada teadmise kujunemise nüansse, mis rangema teadusliku kirjutamisstiili rakendamisel jääksid tabamatuks. Metafoorid avavad võimaluse mänguks tõe alatoonidega.

\section{Soome-ugri välitööde päevikud ERMi arhiivis}

Päevikuid, mida uurime, säilitatakse ERMi topograafilises arhiivis (TA). Nõukogude perioodi välitööde päevikud on ERMi arhiivis hästi esindatud, sest tollal oli töötajatel kohustus ekspeditsioonilt naastes kogutud materjal, sh päevikud, muuseumi kogudesse üle anda. ${ }^{3}$ Tollal toimusid ka olulised arengud ERMi soome-ugri kogumistöös. Teise maailmasõjaga katkenud välitööde organiseerimise praktika käivitati taas 1960. aastate alguses ning 1970.-80. aastad olid pretsedenditu massilise kogumise perioodiks. Seda aega iseloomustab tollase ERMi direktori Aleksei Petersoni kurikuulus „100 eseme nõue“, mida kajastatakse ka päevikutes:

Meid heade soovidega teele saatnud direktor A. Peterson mainis nii muuseas, et kui 100 eset ei kogu, siis ei maksa üle Narva jõe nägu näidata. Me loodame siiralt, et see oli maamehelik nali. Teeme muidugi kõik, et seda „tagasihoidlikku“ " palvet täita, aga... (TA 825:6-7, teadur Heiki Pärdi 1986)

Võrreldes muu materjaliga (kogutud esemed, fotod, joonised, etnograafilised kirjeldused), mille eesmärgiks on edasi anda võimalikult objektiivset infot, on uurijate päevikud isiklikku suhtumist peegeldavad dokumendid. Need sisaldavad palju seesugust infot, mida pole peetud sobivaks või oluliseks märkimaks põhitööna kogutud uurimismaterjali hulka. Tänu vabale esituslaadile on päevikud intiimsemad mistahes ametlikest dokumentidest (vrd Pärdi 1995b: 74).

3 Päris kõik ekspeditsioone kajastavad päevikud ERMi siiski ei ole jõudnud. Päeviku esitamise nõue oli ometi range, nt Edgar Saar on oma 1988. a handi välitööde lõpul kaduma läinud päeviku esitanud mälu järgi taastatud versioonina (TA 848:9). 
Heiki Pärdi (1995b) peab välitööde päevikuid välitöödel toimunu „tahtmatuteks tunnistusteks“. Samas tuleb nende märkmete „tahtmatu“ sõnumi uurimisel olla ettevaatlik. Kuigi ERMi ekspeditsioonipäevikud pole kirjutatud avaldamiseesmärgiga, olid nende autorid teadlikud sellest, et need on arhiivi antuna kõigile kättesaadavad. Vaieldav on „stiilipuhta vahetu (ja avatud) vaatluse“ (Pärdi 1995b: 73) omistamine päevikute kirjutajatele. Vahel on arhiivi antud päevikud puhtandversioonid ekspeditsioonil tehtud ülestähendustest. ${ }^{4}$ Taoline ümber kirjutamine võimaldas kirja pandut veel kord üle mõelda ja toimetada. Hoolimata reservatsioonidest on välitööpäevikud siiski väheseid arhiiviallikaid, kust leiab puhastamata kultuurikonteksti - elu, millest kaevati välja „õige“ materjal (Pärdi 1995a: 27).

Suurem osa ekspeditsioonipäevikutest on kirja pandud ühe autori poolt. Kui tegu oli mitmeliikmelise ekspeditsiooniga, on päevikukirjutamise ülesannet enamasti täitnud välitööde juht. 198ondatel muutus tavaliseks ühispäevikute pidamine - eri päevade sündmusi kajastasid välitöögrupi erinevad liikmed. Ühispäevikutes on sissekanded sageli anonüümsed ja esitatud meie-vormis ning vahel on tagantjärele konkreetse kirjutaja tuvastamine keeruline. Sellele, et varasemaid sissekandeid enne oma muljete kirjapanekut loeti, osutavad sagedased viited kaaslaste kirjutatule, vahel ka järgneva kirjutaja tehtud täiendused ja ääremärkused. Nii iseloomustab ühispäevikuid sõbralikult üksteist aasiv toon, teisalt võidi kollektiivpäeviku vormi kasutada ka rahulolematuse esitamiseks. Ühiselt kirjutatud päevikud kujutavad endast tänuväärset materjali neis sisalduvate dialoogiliste suhete jälgimiseks.

Vaatluse all olevast perioodist on TA-s enim päevikuid Aleksei Petersonilt (17) ja Edgar Saarelt (16). ${ }^{5}$ Nende kahe pikaaegselt ERMis töötanud etnograafi ekspeditsioonikirjeldusete kõrvutamine ilmestab hästi, kuivõrd erinevalt võidi välitööde kogemust kajastada. Saarele on iseloomulik minimalistlik, nähtut ja tehtut konstateeriv väljenduslaad, ta esitab vähe hinnanguid või emotsioone. Meie uuri-

\footnotetext{
4 Näiteks on Heno Sarve 1984. a mokša välitöödelt ERMi jõudnud nii mustand- kui puhtandversioon päevikust (mõlemad TA 798), erinevused kahe päeviku vahel on küll minimaalsed; 1976 . a vadja välitööde päeviku (TA 692) erinevate sissekannete autoritena on märgitud neli ekspeditsiooni liiget, kuid sissekanded on käekirja põhjal tehtud kahe erineva autori poolt, kes ilmselt on algsed märkmed hiljem ümber kirjutanud.

5 Neile järgneb Pärdi 9 päevikuga (1 individuaalne, teised ühispäevikud), Juta Reio 8 päevikuga (neist 3 individuaalsed), Heno Sarv ja Mare Piho on mõlemad andnud arhiivi 6 päevikut (Pihol 3 neist individuaalsed). Kõik nimetatud olid ERMi kauaaegsed teadustöötajad.
} 
muse seisukohalt huvipakkuvaid metafoorseid väljendeid ei kasuta Saar peaaegu üldse. Petersoni päevikud seevastu sisaldavad värvikaid kirjeldusi, tema tähelepanekud on sirgjooneliselt subjektiivsed. Peterson kasutab tihti metafoore ja väljendub kujundlikult, mistõttu pakuvad tema päevikud käesoleva artikli seisukohalt rikkalikku analüüsimaterjali.

\section{Kauplemise metafoorid}

Kaupmehed olid koloniaalsüsteemi agentide seas, keda võidi antropoloogiliste uurimuste sissejuhatuses mainida, ent kes pühiti käsitluste põhiosast välja (Malinowski 2005 [1922]: xii, xv, 4-5; vt ka Geertz 2000: 92; Rubel 2003: 12). Kaupmehed võisid samas ka ise olla etnograafiliste kirjelduste koostajad (Clifford 1986: 118), keda võib leida ka soomeugri etnograafia ajaloost (Latkin 1844). Vaadeldaval perioodil ei olnud teadlaste rivaliteet kaupmeestega soome-ugri välitöödel enam aktuaalne.

Samas on muuseumi kogumispraktikas olnud tavapärane, et esemeid, mida inimene pole soovinud niisama ära anda, on muuseum omandanud raha eest. Seega võib ehk ootuspäraseks pidada asjaolu, et esemete kogumisele keskendunud välitööde päevikutes esineb sageli kauplemisega seotud sõnavara ja metafoore. Päevikutes leiduvad kirjeldused loovad tugeva metafoorse paralleeli etnograafide kogumisretkede ja kaubareiside vahel. Näiteks Petersoni päevikutes on kauplemise retoorika hästi esindatud. Oma sissekannetes mainib ta tihti päeva jooksul omandatud esemeid ning annab hinnanguid tehtud tehingutele. Petersoni päevikutes on tekstilõike, mis on sellisest retoorikast läbi imbunud. Näiteks kirjeldab ta, kuidas päeva jooksul ühes vepsa külas muuseumile esemeid hangiti, läbi korduvate kurtmiste selle üle, et esemeid ei taheta ilma rahata anda, asjade eest nõutakse verehinda ning kogu aeg tuleb maksta (TA 776:26-28, Peterson 1983). Samast Petersoni päevikust leiab kurtmist osturaha nappuse teemal, aga ka müüjate informeerituse üle sellest, kui hästi ta teistele maksnud on:

On juba õhtupoolik kui viimasesse tallu teiselpool küla jõudsime, siit saame veel mõned asjad. Perenaine ütleb, et tuleb maksta, kuna teistele olevat maksnud ja 'не плохо' maksnud. Jah, esimesele objektile sai liialt palju võibolla antud, kuid teised juba said kopikaid. Olgu, ka see saab 15 rubla talle mitte millekski vajalikust träänist. See on ka viimane raha, rohkem pole omalgi peale väikese raha, mis kulub sõiduks tagasi. Rahakotti ju tühjaks päris teha ei saa. (TA 776: 67-68, Peterson 1983) 
Foto 1. Heno Sarv ja Nikolai Mokšin mokša naiselt Jevdokia Šovdinalt särki ostmas. Foto: Jüri Karm 1984. ERM Fk 2086:11

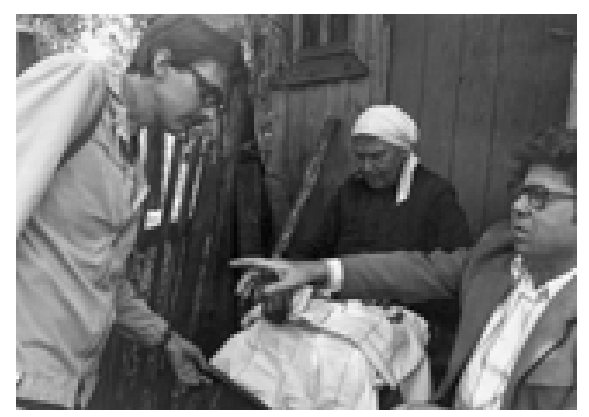

Rahaliste vahendite piiratus kimbutas ka teisi kogujaid. Mitmetest päevikutest leiab arutlusi teemal, et esemete hankimiseks on vajalik hea kauplemisoskus. Ilmneb, et etnograafid hindavad oma osavust hinna üle tingimisel kasinaks:

Ühel tädikesel on sedavõrd huvitavad särgikirjad, et vaatamata rahanappusele jään kauplema [...]. Vaatamata kõigi mu kauplemiskavaluste käikurakendamisele jääb memm kindlaks hinnale 25 rubla särk (mis tegelikult ju polekski sellise meistritöö eest palju - kui endale ostaks) ning sellega tulebki leppida. Nikolai Fjodorovitš [Mokšin] ${ }^{6}$ arvab sellest teada saades, et Eevi Astel ${ }^{7}$ oleks küll minu asemel osanud hinna alla kaubelda. Näiteks võinuks lihtsalt ära minna ja tagasi tulles uuesti läbi tulla. Seda meetodit ma kavatsesingi rakendada samalt meistrilt kõladega kõlapaela kättesaamiseks, mille eest nõuti 10 rubla. Paraku aga tagasi minekul oli tare uks lukus, nii et hea, et särgidki olemas on. (TA 807:16-17, teadur Heno Sarv 1985)

Ühe naise käest, kes oli oma õega kolinud siia Tševernurist, saime kaubelda mäemaride vöö koos puusakaunistustega, mis oli hõbemünte täis tipitud. Heno pakutud zo rubla oli talle nii ahvatlev, et otsis välja veel ühe ehte: suurtest hõberubladest kaelakee. Meie pakutud 6 o rbl. peale arvati, et irvitame nende üle. Ei julgenud pakkudagi rohkem. Siis nimetas ta ise hinna 170 rubla. Oh õudust! Ei aidanud ükski tingimine, tema ei taganenud sammugi, oli kaljukindel: kas 170 rubla või ta ei mü̈̈ üldse. Mis siis muud, kui Heno tõi raha lagedale. (TA 838:51, tudeng Tiia Peedumäe 1987)

\footnotetext{
6 Mordva Riikliku Ülikooli etnograaf, kelle koordineeritud välitöödel Sarv korduvalt osales.

7 ERMi kauaaegne peavarahoidja.
} 
Nagu näha, ei suuda etnograafid loobuda rahvakunsti näidete ostmisest isegi siis, kui küsitud hind ületab kordades esialgset pakkumist. Hinna üle vaidlemisel tabab teadlasi aga pidevalt läbikukkumine, müüjad saavad alati, mida nad nõuavad. Samas tuli ette sedagi, et välitöödele kaasa võetud üliõpilased osutusid osavamateks kauplejateks kui muuseumitöötajad:

Tudengid on kohutavalt õnnelikud, sest Dubrovkast saime päris mitu eset muuseumile välja kaubelda. Nad on mul fanaatilised esemete kogujad. Kr. Raual ${ }^{8}$ oli omal ajal täiesti õige taktika, kui ta just üliõpilased välja saatis. (TA 746:33, teadur Vaike Reemann 1979)

Tavaliselt ületas aga etnograafiline nõudlus pakkumist ja seetõttu domineerisid sellel turul müüjad. Vahel tuli siiski ette, et kuigi vaidlus hinna üle kujunes pikaks, võis see end ära tasuda:

Pärastlõunal õnnestub väike operatiivne kogumisretk sooritada. [...] Natalja Bolšanova juures kaupleme terve tunni puust kammi pärast, mille too on saanud kingiks oma õelt. (TA 798:13-14, Sarv 1983)

Samas juhtus ka seda, et esemete müümisest keeldumisel polnud põhjuseks ainult etnograafi rahapuudus või soovimatus liiga kõrget hinda maksta. „Kaup“ võis katki jääda ka intiimsemal, maailmapildiga seotud põhjusel:

Järgmisena käime Dorofejeva Maria juures esemete ostmise asjus. Ta on omal ajal kulakuna represseeritud, praegugi peab oma töö hinda väga kõrgeks. Prof. Gábor Bereczky ${ }^{9}$ oli temalt poolelioleva puusapõlle saanud 25 rubla eest, mulgi ei õnnestu alla 20 kaubelda. Rüü eest nõuab ikka 25 rubla.

Marjuka Gavrilova juures läheb kauplemine juba veidi paremini, ometigi ei õnnestu pidulikku puusapõlle (kettidega) kaubelda ta tahab seda tütrele pärandada. Marjuka tahab end lasta ersa rahvarõivais matta. Selleks on tal ka pärnaniinest viisud hoitud. (TA 782:8, Sarv 1983)

See juhtum näitab, et kultuurispetsiifilised arusaamad mõningate esemete erilisest rollist olid säilinud. Samas võib eelnevalt esitatud kulakliku suhtumise süüdistust käsitleda Sarve aasimisena ihaldatud

\footnotetext{
8 ERMi asutajaliige ja vanavara kogumise peakorraldaja muuseumi algusaegadel.

9 Ungari fennougrist.
} 
esemete omaniku aadressil. Tuli ette ka seda, et rahvarõivaste üle kauplemise „laat“ lõppes ebaõnnestumisega vihmapilve saabudes (TA 807:10, Sarv 1985). Teiselaadse, ent eriti ajastuomase seigana leidub näide ka bartertehingust:

Siit saime ühe ree, ôllepüti jne. - kokku üle 10 asja. Jälle probleem rahas. Õnneks mitte palju ca 5 rubla pakkusin ja andsin paar kilekotti. Sellega oli asi korras. Üldse paistab, et ega inimesed (osa) nii rahaahned pole, ajavad piskuga läbi. Ka teine naine toob paar vitstest punutud asja. Nende eest tasun samuti 2 kilekotiga. (TA 776:74, Peterson 1983)

Kilekottidega kauplemine võis olla tollal levinumgi. Vahel võidi kilekotte ka inimestele kinkida tänuks külalislahkuse ja konstruktiivse koostöö eest:

[...] tänutäheks kinkisime mõlemale [abikaasadest] muuseumi kilekoti. Nende üle on siinkandi rahval siiralt hea meel ja meie arust on see üsna kena komme, lahkudes muuseumi poolt selline väike meene maha jätta. (TA 742:46, teadur Katrin Liias 1979)
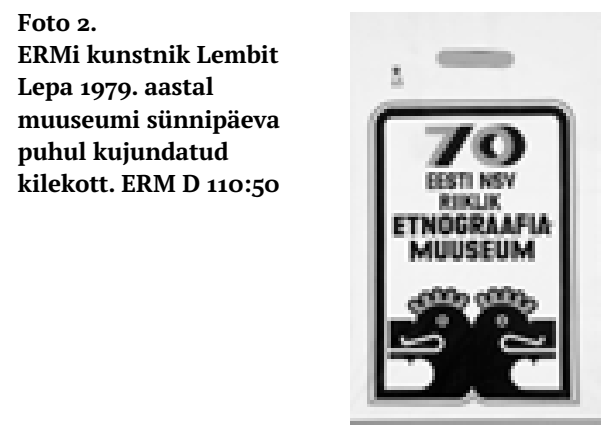

Kilekott olid Nõukogude Liidus eriti 1970ndatel, aga ka veel 198ondatel aastatel defitsiitne kaup ning staatuse sümbol. Tagantjärele tundub hindamatute etnograafiliste esemete vahetamine kilekottide vastu groteskne tehing (samuti oleks see tänapäeval kergelt kentsakas valik tänutäheks jäetava meene valikul), ent tollal olid mõlemad pooled tulemusega ilmselt ülimalt rahul. Kogujate jaoks oli defitsiidiks etnograafilised esemed, soomeugrilaste jaoks aga kilekotid. Ja ega ERMi töötajatel olnud kilekotte lihtne saada. Antud juhul oli päästvaks asjaoluks see, et muuseumi juubeli puhul oli tehtud spetsiaalne kilekott.

Korduvalt tuleb kogumistöö kirjeldustes esile laiemale nõukogude argielule viitav terminoloogia, seeläbi seostatakse esemete kogumine muuseumile inimeste üldisema kogemusega erinevate tarbekaupade soetamisel. Keskseks märksõnaks on siinkohal 
„hankimise“ mõiste, mis nõukogude ajal osutas defitsiitse, raskesti kättesaadava kauba omandamisele:

Imekombel õnnestus hankida ka mõned esemed. Jälle töö- ja tarberiistad! Ei ühtki tekstiili. (TA 692:27-28, Pärdi 1976)

Pildistasin külas. Siin on toredad sammasaidad. Esemeid rohkem ei õnnestunud hankida. (TA 748:21, teadur Edgar Saar 1980)

Hankisin muuseumile rü̈̈, kindad, helmestega kaunistatud sussid ja nõelapadja. (TA 748:48, Saar 1980)

Meile anti 2 toaline köögi ja kempsuauguga korter. Enne sissekolimist läksime uurimis-hankimisretkele. (TA 858:15, kunstnik Anneli Säre 1989)

Nõukogude defitsiidimajanduse metafoorne ülekandmine etnograafilisele kogumistööle on ootuspärane, sest taolised väljendid olid tollal inimeste igapäevases suhtluses harjumuspärased ning etnograafide tegevuse sarnasus kaubandusvorrgus tegutsemisega tajutav. Peterson kasutab ka „äri ajamise“ kujundit:

Käime majades. Serafima ees ja teised järel, ka minul pole erilist vaeva. Eeltöö teeb Serafima, siis kui midagi paistab, asun tööle, kauplema. Harilikult ütlevad nad, et ei tea, palju maksab, mis kui nimetad hinna, mina nimetan madala hinna, isegi Serafima paneb vahel pahaks - inimesele peaks ikka asja eest maksma! Mina jälle: „Egas me omale kauple, see on kultuuriväärtuste kogumine, nagunii lähevad need tekstiilid kaotsi." Neid ei saa võrrelda tänapäeva ostuasjadega. [...] Mul pole ka enam osturaha, sellepärast pole võimalik aktiivset äri ajada. (TA 719, Peterson 1978)

Äriga tegelemisena kirjeldab esemete hankimist ka Sarv:

[...] käin viisumeistri juures. Meistri proua paistab äriinimene olema, niisiis lepime töö hinnaks 3 rubla kokku. Õhtuks lubatakse viisud valmis teha. (TA 782: 28, Sarv 1983)

Päevikutes leidub ohtralt kapitalistlikele vahetusviisidele viitavat retoorikat nagu ka eespool näha. Keskendumine kapitalistlikele rahaliskaubanduslikele suhetele kätkeb endas nõukogude aja kontekstis ka ehk teatud vaikset irooniat valitseva režiimi suhtes. Petersoni kirjelduste puhul tekib seesugune tunnetus ilmselt autori vastava kavatsuseta, kuid näiteks 1989. a päevikus kujutab Pärdi ekspeditsioonigrupi tegevust juba varjamatu eneseirooniaga: 
Tõeliste rändkaubitsejate-harjuskitena oleme käigult omandanud peamiste nõudluskaubaartiklite komikeelsed nimed nagu єёнь - vö̈, дӧрӧм - naiste särk, чувки - kirisukad, mуес tohtnõu, necmepb - seljakorv (tohust) ja veel mõned sarnased. (TA 858:31-32, Pärdi 1989)

Mitmest eelnevalt toodud näitest kumab läbi etteheitev suhtumine sellesse, et inimesed etnograafi silmis museaalse väärtusega asjade eest (liiga kõrget) tasu nõuavad. Kohati on need etteheited esitatud küll teatud vastuolulisusega - kaeveldakse asjade kõrge hinna üle, samas tunnistatakse, et esemed on tegelikult küsitud hinda väärt. Taolistel puhkudel ilmneb kirjutajas identiteedikonflikt - ühelt poolt n-ö tavalise inimese, teisalt muuseumitöötaja vaade, viimane lähtub seejuures mingist „kõrgemast“ ja ebaisikulisest kultuuriväärtuste säilitamise ideest. Igal juhul on pinge omandada piiratud ressursside juures võimalikult palju ja võimalikult ,häid“ esemeid soome-ugri päevikutes läbivalt kajastatud. Kui jõuliselt see diskursus esile tuleb, sõltub konkreetse kirjutaja hoiakust ja stiilist. Vahel pole aga visast kauplemisestki kasu, sest inimesed osutavad aktiivset vastupanu ning esemete kättesaamise nimel tuleb etnograafil lahingusse astuda.

\section{Sõja metafoorid}

Constance Classen ja David Howes (2006: 209) on kirjutanud sellest, kuidas teiste rahvaste esemete kogumise praktika Lääne ajaloos on olnud teatud laadi allutamise vorm. Kogutud esemed kujutavad endast selles kontekstis sõjasaaki, teisalt mõistsid 19. sajandi kollektsionäärid oma tegevust esemete „päästmisena“. Seesuguseid kontseptuaalseid hoiakuid kajastavad ka ERMi välitööpäevikud. Esemekogujate lähenemises oli neil loomulik õigus inimestelt muuseumi jaoks asju saada. Taoline suhtumine tekitas kohati ka vastuseisu. Nagu näitavad varasemad päevikud, on see probleem olnud pidevalt päevakorras. Nõukogude ajal (Petersoni ajal, kes oli ERMi direktor 1958-1992) peeti muuseumi huve kõrgemaks inimeste huvidest. Analüüsitud päevikutest leiab sellise suhtumise kõige jõulisemalt ja ootamatult sirgjooneliselt esitatuna just muuseumi tollase direktori sõjakas sõnastuses:

Edasi liikudes saame kokku mehega kes hommikul meie külas hobust käis toomas. See [...] otsib üles meile mitu eset. Siin pääseme ka ühe riidekirstu juurde kus vanemaid rõivaid on. Kasutades [...] naise puudumist, võtan siit kaasa mõne tekstiili. Mis teha, kultuur, rahvakultuur nõuab ohvreid mitte ainult nende kogujatelt vaid ka nendelt, kes seda loovad ning on senini 
kirstudes hoidnud. Õige koht on nendel asjadel muuseumis, ja nii ma võtangi kaasa, ilma erilise südamevaluta, et olen kellelegi liiga teinud. (TA 776:54-56, Peterson 1983)

Muuseumile esemete kogumist mõtestatakse kultuuriväärtuste säilitamisena, mis toimub ühiskonna hüvanguks. Taolise vaate rakendudes omandavad kohalikud inimesed, kui nad esemeid loovutada ei soovi, mässuliste või ka ohvrite kuvandi. Välitööde kogumistegevuse probleeme kajastatakse päevikuis tihti kohalike inimeste vastupanu kirjeldamise kaudu.

Me ekspeditsiooni aeg hakkab lõpule jõudma. Juba praegu võib öelda, et me asjad arenesid normaalselt, asju saime ja saame ka normaalselt, s.t. suure vaeva ja pealekäimisega ikka saab. (TA 776:6o, Peterson 1983)

Edasi saime küll suusad, kuid sellele lisandus jama, sest ema andis, aga poeg keeldus. Õigemini nõudis juba äravormistatud lumelaudu tagasi. (TA 679:23, Peterson 1976)

Külastasime üpriski mitut tädi, kellest üks jäi meelde oma suure visaduse poolest. Küll püüdsime meie (vene ja komi keeles) ning tema tütar ja naabrinaine teda veenda, et ta ühe tohust huvitava nelinurkse kujuga aluse meile annaks, aga asjata. Tädi jäi endale kindlaks. Otsis isegi aidast vana sarafani ja muud nipet-näpet meile asemele (et me ta rahule jätaksime), kuid seda tohust asja ei andnud. Lõime käega [...]. (TA 858:23-24, Terje Alop 1989).

Päevikutest leiab näiteid ka äratuntavamalt sõjaga seotud metafoorsete väljendite kasutamisest. Etnograafilist välja kujutatakse lahingutandrina, kus vaenlast rünnatakse senikaua, kuni ta lõpuks alistub. Pealetungi alustuseks atakeeritakse vaenlast ülekaalukate jõududega:

Üldiselt oli esimesel silmapilgul veidi pikaldase ja võib olla kohtlasenagi tundunud E. J. vägagi teravmeelne ja vaimukas. See lihtsalt ei avaldunud meie esimese äkkrünnaku ajal, kui maja ja õu täitusid korraga 9 inimesega. (TA 852:49, teadur Marika Mikkor 1988)

Üllatusmomendi kasutamist esemete kättesaamiseks kirjeldatakse teiseski välitööpäevikus, kus raporteeritakse, et toimus „kiire rünnak pererahvale“" (TA 834: 22, videooperaator ja fotograaf Aado Lintrop 1987). Kallaletungi võib alustada ka mitmel rindel korraga. See on 
eriti põhjendatud juhul, kui teine leer on etnograafe provotseerinud omapoolsete küsimuste ja agressiivse kostitamisega:

Tütar on Olgal sama hakkaja kui ta isegi, sest kohe kui tulime, oli ta krapsti vastas, surus meid tuppa ja pani teevee tulele. Tütar hakkas meid küsimustega pommitama, ise imestades, et miks meil tõlki (st. Maret) kaasas ei ole. Varsti tuli ka Olga Jegorovna ja me jagunesime: Piia asus ahju kallale, meie Olga Jegorovna kallale. Ei ütleks, et eriti palju andmeid saime, aga siiski üht-teist saime. Tunni aja pärast kutsuti meid lauda ja sunniti sööma. Eriti tore oli vaadata, kuidas peretütar ahastavalt talle otsa vaatavale Sirjele käskivalt kordas: „Šöö, šöö!“ (TA 834:33-34, tudeng Terje Alop 1987)

Metafoorses sõjategevuses etnograafide ja kohalike vahel võib initsiatiiv seega käia käest kätte. Pettemanöövrina võib rünnaku ka peatada ning taanduda, et korrastada jõude ning ümber grupeeruda:

Avama tuli vana kõhn naisterahvas, ruuduline suurrätt ümber. Hiljem selgus ta nimi - Tatjana Kondratjeva. Pärast mõnda isurikeelset lauset läks jutt millegipärast edasi vene keeles, siis tekkis väike segadus ning Reet ja Iivi otsustasid taanduda. Lahkusin kahetsusega, sest tundus, et oleksime võinud yht-teist teada saada. (TA 769:25, Lintrop 1982)

Otsustava tormijooksu eel on aga oluline vaenlase strateegilised sihtobjektid fikseerida ning valida rünnakuks sobiv ajahetk (halva ilmaga istuvad inimesed kodus paigal ega jookse küla mööda laiali):

Eile ôhtul, kui ilm nii süngelt külm ja tuuline oli, arvasime sellest hoolimata, et tarvis ikka ära käia Liivtšulö-Luuditsa ringil. Kuna sealne klubijuhataja mul niikuinii sihikul oli. Et seda ilusat ilma võime siia ootama jäädagi ja ega me suhkrust kah ole. Nii et! (TA 836:17, bibliograaf Juta Reio 1987)

Lõpuks saavutatakse aga vastase tingimusteta kapituleerumine:

Talu bussi juures oli tühi meie jaoks s.t. sealt ei saadud ühtki eset, aga juba järgmises talus tegime otsa lahti. Tädi ajas etnograafidega juttu, näol tagasihoidlik, alistunud ilme „Tuleb ära kannatada“. (TA 852:5, teadur Terje Alop 1988)

Seega katavad ERMi soome-ugri päevikutest leiduvad kirjeldused sõjakäigu eri faase ja taktikalisi käike. Tuleb muidugi arvestada sellega, et esitatud „sõja“ käik on päevikutest korjatud fragmentidest 
konstrueeritud. Samas ilmneb seegi, et sõjaga seotud metafoorid on ilmekad ja mitmekesised, andes kaugel maal toimunud etnograafilistele välitöödele juurde põnevust ja dramaatikat.

On huvitav, et kohalike elanikega „sõdimist“ tuli ette juba ka Eesti esimese põlvkonna etnograafil Gustav Rängal tema Karjala välitööde käigus (TA 610:11, 52; vt ka Nõmmela 2007a: 55, 60). Nii et sõja ja vastupanu diskursuse kujunemise võime tagasi viia Eesti professionaalse etnograafia algusaega ning tegelikult varasemassegi perioodi, kui ERMi jaoks kogusid esemeid asjaarmastajatest kaastöötajad (vt Jans 2006 [1920]).

Foto 3 .

Aleksei Peterson kannab Komimaal kogutud esemeid. Foto: Vello Kutsar 1976. ERM Fk 1793:107

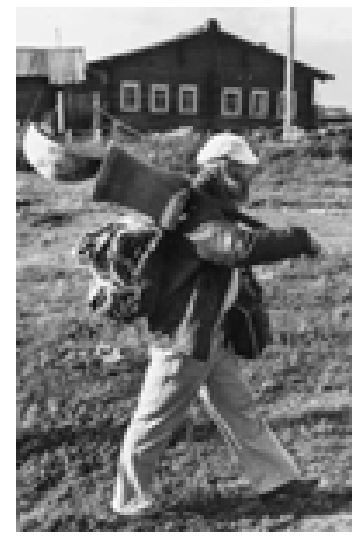

Samas pole selge, milline praktika tegelikult kaasnes taolise tekstiga, kus esemete kogumist kujutatakse metafoorselt kui rasket võitlust vaenulike jõududega. Petersoni ekspeditsioonidel keskenduti varjamatult esemete ekstensiivsele kogumisele ning sedasama tema päevikud ka selgelt kajastavad. Teisalt leiab päevikutest küllalt näiteid ka sellest, et kohalikud inimesed kasutasid meelsasti võimalust kodus leiduvate „etnograafiliste esemete“ müügist lisasissetulekut teenida ning olles kuulda saanud muuseumitöötajate viibimisest külas, mindi neile ise asju pakkuma (TA 837:36, 39, Sarv 1987; TA 838:52-53, Peedumäe 1987). Seega anname endale aru, et üldine pilt on päevikutes tasakaalustatum, kui meie poolt välja joonistatud jõuliste diskursuste järgi võib tunduda. See on eriti oluline meeles pidada sõja metafooride, ent vähemal määral kehtib tasakaalustava hoiaku vajadus ka saagi metafooride puhul. 


\section{Saagi metafoorid}

Toome järgnevalt esile rea väljavõtteid ERMi päevikutest, milles kirjeldatakse kogumistööd saagi metafoori kaudu. Osa neist osutustest on üldisemat laadi, kus kogutud esemeid käsitletakse üldsõnaliselt saagina, ent mingeid tähenduslikumaid nüansse ei lisata. See ilmneb tihti Petersoni päevikutest, kust on võimalik suurema vaevata saagi metafoori kasutamise näiteid välja noppida:

Muuseumi kogud täienesid ca 180 esemega, ca 400 pildistust + 10 tundi makilinti. Hea saak! (TA 679:82, Peterson 1976)

Saak osutub üsna soliidseks, päev on jälle kasulikult veedetud, ja mis peaasi muuseumikogud on täienenud väärtuslike eksponaatidega. (TA 776:57, Peterson 1983)

Niisiis järjekordne Vepsa reis on ajalugu. Mida siis taotlesime, mida saime? Seda pole kerge vastata, sest eks hinnangu annab alles aeg. [...] ka esemeid saime üsna hästi - üle 15o. See pole väike saak. Ka lindistusi saime ca 4 tundi. See on keskmine saak. Palju Jüri Karm ${ }^{10}$ tegi pildistusi, praegu ei tea, loodame et need enamikus ka õnnestusid, loodame, sest vahepeal jukerdas tal fotoaparaat. Niipalju saagist. (TA 776:93-95, Peterson 1983)

Sellised üldised osutused näitavad, et esemete saagiks pidamine oli etnograafide kogukonnas väga tavaline hoiak. Mõnikord on päevikutes ka täpsemalt osutatud, millisele „saagile“ metafoorselt osutatakse. Näiteks järgmises päevikuväljavõttes on selge, et kogumist võrreldakse jahindusega:

Päikeseloojanguni jahime veel esemeid: loojanguaeg on ideaalne kogumisaeg - see on vanaemade dispetšertund. Kuni pereemad loomi koju ajavad, istuvad vanaemad värava ees pingil, vahetades uudiseid. See aeg kestab 2-3 tundi: lounapoolseil maadel loojub päike kiiremini kui meil Eestis. (TA 782:32, Sarv 1983)

Heno Sarve arutlus ilmestab asjaolu, et nagu jahimees peab hästi tundma metsa ja sealseid asukaid, nii tuleb ka kogujal teada inimeste kultuurilisi harjumusi ja igapäevast elurütmi. Samadel välitöödel kasutab Sarv veel korra tulundusega seotud metafoori, mis võib olla seotud nii küttimise kui ka kalapüügiga:

10 ERMi fotograaf. 
Viktor [Danilov] ${ }^{11}$ võtab magnetofoni kaasa ja läheme laulikuid ning muid teadjaid otsima. Lindil on söödaks mõned varem lindistatud laulud. Saamegi ühes peres jutule. Laule kuulatakse heameelega, käsitööst pole midagi pakkuda ning ka ennast arvatakse mitte heaks laulikuks, soovitatakse aadresse. (TA 782:17, Sarv 1983)

Söödaga saagi püüdmine, nagu ka kütitavate harjumuste ja keskkonnatingimuste tundmine on olulised nii jahimeestele kui ka kaluritele. Viktor Danilov ja Heno Sarv ilmutavad kogujatena etnograafilist nutikust, mis on märk nende vilumusest. Peterson kasutab oma udmurdi päevikutes kogumistöö iseloomustamiseks tihti ka selgelt kalastusega seotud metafoore, nagu näiteks järgmisel juhul: „Peale paari maja läbikäimist näkkabki juba“ (TA 783; vt ka Karm 2006: 165). Õngitsemise kujundi kasutamisel kogumistöö kirjeldamisel pole Peterson ka päris üksi:

Šeliššäl võtsime õnge veel Manitševa ja Palaga-tädi, viimane ei oska küll üldse rääkida, seda peab kahjuks tunnistama. Küsimustele vastab ta kahe sõnaga, seeeest on ta suurim asjatundja külajuttude osas. (TA 746:25, tudeng Marie Vinkel 1979)

Lisaks kogumistöö kirjeldamisele sarnasena küttimise ja kalapüügiga seostatakse esemete kogumist ka röövimisega. Päevikutest leitavad näited pole selles osas eriti selged, ent vähemalt vihjamisi on see tunnetuslik side tajutav. Näiteks kirjeldab Sarv välitöödel osalenud tudengite naasmist ühelt hommikuselt käigult röövitud varanduse kohale toimetamisena: „Kell 12 tulevad tüdrukud [üliõpilane Tiia Peedumäe ja kunstnik Reet Ohna] järjekordse noosiga“" (TA 837:31, Sarv 1987). Sarnast röövliretoorikat kasutab kogumise iseloomustamisel ka Pärdi: „Ei sõida täna Jõgõperäle, kust eile hea noosi saime, vaid tegeleme tuleviku kindlustamisega Liivčyläs ja Luudzas“" (TA 742:48, Pärdi 1979). Ebamäärasemalt seostub röövimise metafooriga ka osutus sellele, et külade „läbikammimist“ tehakse süstemaatiliselt (TA 837:15, Sarv, 1987). Etnograaf Ülo Maaringu teates ühendatakse aga tegutsemine videviku ajal ning küla läbikammimine: „Õhtune saak oli läbikammitud kylas kyllaltki kena: 6 eset“ (TA 681:24, Maaring 1976). Ühel korral kirjeldab Sarv kogutud esemete pakkimist, kasutades vihjet hämaruses tegutsemisele enne „kuriteopaigast“ lahkumist: „Ööpimeduse varjus hotellitoa lambi valgel valmistame esemepaki ja pakime seljakotid“ (TA 782:32, Sarv 1983).

11 Ersa folklorist. 
Esitatud näited ilmestavad viisi, kuidas etnograafid välitöödel oma tegevust millegi röövimisele sarnasena kirjeldasid. Meie kogemus näitab, et muuseumitöötajate suulises pärimuses on nõukogude aja välitööde meenutamisel röövimise metafooril suurem roll, päevikud seda nii ilmekalt ei kajastagi, kui ehk mõned juhtumid välja arvata. Röövimislaadsele tegevusele viitavad mõned Petersoni kirjeldused sellest, kuidas ta inimeste kodudes panipaiku puistab, näiteks järgmine lugu tegutsemisest Komimaal:

Vanamees on tõesti olemas. [...] Kuid jutust minul ei tule temaga midagi välja. Lihtsalt ikkagi on vähe minu jaoks tema vene keele oskusest ja ka kuulmisest. Naine on noorem, aga samuti ei kuule hästi. Selle-eest ta sõimab meid kõiki ja hoiab silma peal, et midagi „sisse ei vehitaks“. Ja kui me tema nägemata sarais käisime ja mõrra alla vinnasime, siis sai veel pahasemaks ning vastas ainult „abu“ - ei ole - ja nähtavasti veel kõvemini komi keeles, millest muidugi mina tuhkagi aru õnneks ei saa. (TA 679:33-35, Peterson 1976).

Ja teine juhtum, kui ta Udmurdimaal justkui möödaminnes praktilisest vajadusest koti kaasa haaras:

Nüüd võtan oma esemekoti ja lähen esemeid ära saatma. [...] Aga kotti, mis ma olin ühest aidast virutanud, ei võetud vastu paigad on väljapoole pandud. (TA 719, 17.07, Peterson 1978)

Vahel juhtus ka, et ekspeditsiooni liige, kes ise esemete kogumisel aktiivselt ei osalenud, kirjeldas kolleegide kogumistegevust kriitiliselt (TA 837:22, Lintrop 1987). Seega pole avaliku varguse metafoori kasutamise alati humoorikas, vaid võidakse tunda end ka häirituna pealesunnitud liigsest keskendumisest asjadele. Masskogumise keskne lähenemine kõigile välitöödel käijatele ei sobinud ja leidub veel sellekohaseid sissekandeid (nt TA 836:15-16, Reio 1987)

Välitööde päevikutes on saagi metafoorid tihti tajutavalt koomilised, ehkki vihjed jäävad üldjuhul looritatuks. Vahel on huumorimoment aga ka selgelt esiplaanil. Omavahelises vestluses, mida vahel harva on ka päevikutes kajastatud, matkitakse Petersoni, ent ollakse oma intensiivse kogumistegevuse suhtes siiski ka mõnevõrra kriitilised, nagu juhtus 1989. aasta komi kogumisretkel:

Pärastlõunal asusime põhitöö - kogumise juurde. Mind kui ekspeditsioonirebast pisut hämmastas see, kui Komi muuseumi 
töötaja pr. Nadežda' ilma pikema sissejuhatuseta kohe asju nõudma hakkas. Aga noh, ju see nii käibki. Igatahes Terje väitis, et kui ta oleks Peterson, oleks ta saagiga rahul (TA 858:13, tudeng Eve Randoja 1989).

Külast kogusime triikraua, sarafani, ühe pešteri, koonlalaua, kanga koos soa ja niitega, süstikuid 2 tk. Terje ütles, et kui tema oleks Peterson, siis jääks ta selle saagiga rahule. (TA 858:17, fotograaf Aldo Luud (?) 1989)

Heno Sarve ja Tiia Peedumäe päevikud 1987. aastast (vastavalt TA 837 ja TA 838) kujutavad endast huvipakkuvat materjali põhjusel, et tegu on sama ekspeditsiooni kajastustega. Võib eeldada, et välitööde käigus teineteise päevikuid ei loetud. Sarv oli selleks ajaks juba kogenud välitöödel käija, hiljem samuti ERMis töötanud Peedumäe oli aga veel tudeng ja tema jaoks oli tegu esimese välitöökogemusega. Sarnaselt ühispäevikutega leidub näiteid sellest, kuidas nendeski päevikutes korduvad väljendid, mis nähtavasti olid grupiliikmete seas aktiivses kasutuses. Kui Peedumäe kasutab kogumistööst kõneldes korduvalt „saagi“ metafoori, siis Sarve päevikus ei esine see kordagi. Samas saame Peedumäe kaudu teada, et Sarv samuti seda väljendit kasutas:

Meie tööks on talust tallu käimine ja muuseumile esemete kauplemine. Õigemini kauples [Nikolai] Mokšin, meie ülesandeks oli saak laagrisse toimetada. (TA 838:8, Peedumäe 1987)

Saak oli hommikupoole päris korralik, suurematest asjadest saime voki ja peale selle veel üht-teist väiksemat kraami. (TA 838:14, Peedumäe 1987)

Tänaseks saagiks on põhiliselt särgid ja šarpanid (rahvuslikud peakatted). (TA 838: 49, Peedumäe 1987)

Mul sai täna hommikul külas jälle film täis, muidugi polnud kellelgi sobivat filmi kaasas. Kahju, et palju huvitavaid, väärtuslikke kaadreid minul jäädvustamata jäi. Heno naljatas, et tema juba lootis, et täna peaks hea saak tulema, kui minul film otsa sai. (TA 838:55, Peedumäe 1987)

12 Nadežda Titova, osales koos eestlastega Komi välitöödel aastatel 1976, 1989 ja 1997. 
Saagi metafoor on üks läbivamaid soome-ugri päevikutes ja võib-olla Eesti etnograafide päevikutes üldse. Välitöödel kogutud esemete kui saagi üle arutelu esineb näiteks ka Gustav Ränga Karjala välitööde päevikus 1929. aastal (TA 610:19, 76; vt ka Nõmmela 2007a: 54, 56). Enamik soome-ugri rahvaid elab Eestist kaugel, nende elukeskkond on eestlastele võõras. Taolistesse paikadesse rännanud etnograafidel oli tunnetuslikult sobiv kujutada end seiklevate kaupmeeste, sõdurite, küttide, kalurite või röövlitena.

Foto 4.

Ingeri ekspeditsioon

hakkab lõppema.

Kogutud esemed on

kärusse laaditud, ees

seisab kodutee.

Foto: Aado Lintrop 1987.

ERM Fk 2207:186

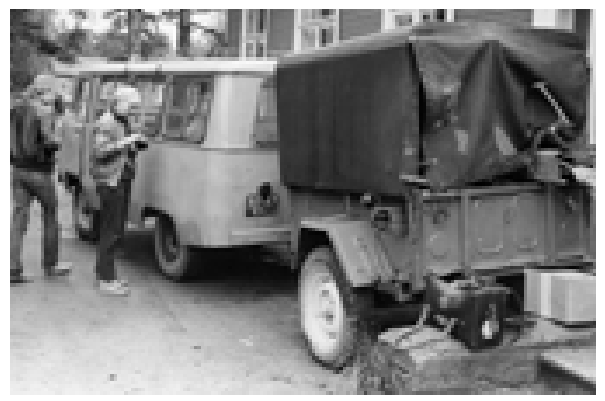

\section{Kokkuvõte}

Kogumisel esemete arvukusele keskendumise kirjeldused on päevikutes domineerivad. Petersoni päevikutes on need kirjeldused siirad (sest esemete kogumisretkedega sisuliselt tegu oligi). Mõni teine autor vaatleb oma kogumisele kontsentreeritud tegevust aga pigem läbi huumori- või irooniaprisma.

ERMi soome-ugri päevikute analüüsimisel keskendusime vaid mõnele ilmekamale diskursusele, mis on seotud kauplemise, sõjapidamise ja saagi metafooridega. Peterson on kauaaegse direktori, nõukogudeaegsete soome-ugri ekspeditsioonide algataja, jõulise isiksuse ning ekspressiivse olustikukirjeldajana paradigma seadjaks soome-ugri välitööde päevikute kirjutamisel ERMis. Samas esineb sarnaseid metafoore (näiteks saagi ja sõjaga seotuid) juba ka Gustav Ränga 1929. aasta Karjala välitööde päevikus. Seega on võib etnograafiliste esemete kogumine välitööde vormis suunata kogujaid teatud viisil mõtlema ja kirjutama.

Intuitiivsete, olukordade sarnasusest tingitud seoste kõrval leidub päevikutes ka intertekstuaalseid ja etnograafide kogukonnas levinud diskursiivsest stiilist tulenevaid analoogiaid. Selles mõttes on kindlasti peamiseks inspireerijaks Peterson, kelle jõulisi töömeetodeid ning joviaalset kirjeldusstiili järgitakse, samas end direktori lähenemisest huumori ja groteski abil tunnetuslikult distantseerides. 
ERMi arhiivis leidub üle 1000 välitööde päeviku (nagu eespool märgitud, on 139 nendest kirjutatud soome-ugri välitöödel, millest omakorda 80 jäävad käsitletavasse perioodi ning käesolevas uurimuses kasutasime 20 päevikut) ning oleks ennatlik teha põhjapanevaid üldistusi murdosa tekstide põhjal. Ehkki kauplemise ja saagi kujundeid etnograafi töö kirjeldustes leidub soome-ugri päevikutes silmatorkavalt, on samas ka päevikuid, kus neid üldse ei esine. Direktori, eelnevate kirjutajate või ka välitöökaaslaste sõnavara kopeerimine võis toimuda teadlikult, aga ka ebateadlikult ning enamasti on võimatu tõsikindlalt väita, millega just tegu on. Olgu need metafoorid välitöökirjeldustesse jõudnud teadlikult või spontaanselt, ent neid on peetud kogetu edasiandmiseks sobivaks ning vastavas keelekasutuses peegeldub läbielatu vahetu mõtestamine.

Analüüsitav materjal päevikute näol ei võimalda meil paraku kuigi palju teada saada teise poole ehk kohalike inimeste mõtetest ja tunnetest. Etnograafi jutt kauplemisest ja saagist mõjub küll sõjakalt või kasuahnelt, kuid kohalik inimene, kellelt „saak“ või „träni“ saadi, jäi tehinguga mõnikord väga rahule (TA 837:39, Sarv 1987). Muuseumi ootus, et välitöödelt toodaks kaasa võimalikult rikkalik täiendus kogudele ning ka tollase direktori isiklik eeskuju suunas samuti väljenduma osava küti, röövli või eduka kaupmehe retoorikas.

Seega ei kujunda päevikutes leiduvate väljendite ja metafoorsete kujundite kasutamist ainult vahetu kogemus, vaid ka teadlaste kogukonnas ning ühiskonnas laiemalt levinud kirjaliku väljendumise viisid (vt näiteks Atkinson 1994: 110; Biolsi ja Zimmerman 1997: 7). Clifford Geertz täheldab antropoloogilise teksti näiva faktiselguse ja kirjandusliku pretensioonituse taga tegelikku sõnamängu läbi kujundite, metafooride ja fraseoloogia, nii et etnograafilisi kirjutisi võiks võrrelda luuletuste ja romaanidega ,...tõelisest imbumisest [...] teise eluvormi“" (1997 [1988]: 4-5).

Kogumisretkedel tihtipeale ei toimu etnograafide sulandumist uuritavasse kogukonda, mis võimaldabki selgemat vastasseisu esitlemist kohalike inimestega kauplemise, sõjakäigu ja saagi metafooride kaudu. Ranges mõttes polegi metafoore ehk päevikutes väga palju, aga need tekstid sisaldavad siiski ohtralt metafoorsust laiemas mõttes. See võimaldab rakendada Lakoffi ja Johnsoni lähenemisviisi.

Kauplemise, saagi ja noosi (catch) metafoorid kuuluvad Lakoffi ja Johnsoni järgi olemismetafooride hulka, mis võimaldavad „sündmuste, toimingute, emotsioonide, ideede jmt käsitlemist entiteetide ja ainetena“ (Lakoff ja Johnson 2011: 58). Need „on tarvilikud juba selleks, et üritada oma kogemusega mõistuslikult toime tulla“ 
(samas: 59). Sõja-, jahi- või röövsaagi ning kauplemisega seotud metafoorid on ühelt poolt tõestuseks, et etnograafide päevikud on kogemuse vahetud tunnistajad (ja selles mõttes on õigus Heiki Pärdil, kui ta välitööpäevikuid taolistena käsitleb). Lakoffi ja Johnsoni järgi ei saa inimesed tavaliselt arugi, et taoliste väljendite kasutamine võiks olla midagi muud kui tegelikkuse realistlik edasiandmine:

Sedasorti olemismetafoorid on nii loomulikud ja meie mõtlemises nii valdavad, et neid peetakse tavaliselt vaimsete nähtuste enesestmõistetavateks ja otsesteks kirjeldusteks. Enamik meist ei adu tõsiasja, et need väljendused on loomult metafoorsed. (samas: 62)

Teisalt, kui me läheneme tekstiloome, sealhulgas intertekstuaalsete seoste kasutamise seisukohast, siis on näivalt vahetut muljet võimalik ka tagantjärele konstrueerida ning see võimaldab etnograafilisele tunnetusele mõtestatumat sisu anda. James Clifford (1986: 119) väidab, et välitöödel kogutud etnograafilised andmed ja dokumenteeritud tõsiasjad „omandavad tähenduse alles narratiividesse korrastatult, olles kokkuleppelised, poliitilised ja tähenduslikud laiemalt kui ainult faktide esitamise mõttes.“

Metafoorid on kõnekad etnograafilise tunnetuse peegeldajad. Samas pole need võluvahendid kogu teadusliku protsessi mõistmiseks. Kirjutajad ei pruukinud alati mõelda metafooride kontekstis ja pole välistatud, et lugeja ise need vahel sinna sisse loeb. Tihti on metafoorne kirjeldus implitsiitne, tajutav päeviku kirjete tausta või mudelina. ERMi päevikute koostamist mõjutasid lisaks etnograafide isiklikele muljetelemõtetele ka institutsionaalsed (juhtkonna nõuded) ja sotsiaalsed asjaolud (välitöödel rakendatud ühise päeviku pidamise meetod), aga ka teadmine isikuandmete ja kirjapandud mõtete kaitsmatusest (arhiivis on päevikud avalikud).

Metafooride kaudu päevikute uurimine on üks võimalusi etnograafilise teadmise kujunemise käsitlemiseks. Taoline lähenemisviis on erinev fakti- ja teooriapõhisest mõistmisest, on intiimsem, subjektiivsem, inimlikum ning avab seeläbi uusi perspektiive Eesti etnograafia ja museoloogia kujunemisloole.

Välitööde protsessi vahetul kajastamisel rakendatud metafoorid peegeldavad ERMi tollase kogumistöö seoseid nii pikaajaliste kui ka ajastuspetsiifiliste museoloogiliste arengutega, aga ka kogujate arusaamu nende töö olemusest. Nõukogude ajal võimaldasid metafoorid kirjutada etnograafilist kogemust nii-öelda ridade vahele. Ühiskondlik rusutus üldiselt, aga ka muuseumitöö range raamistus ei võimaldanud otsesõnu dokumenteerida tegelikkust ja segasid igasuguse inimliku kogemuse vahetuid väljendusi. Soome-ugri rahvaste seas 
rännates lisandub ka võõra kultuurikeskkonna mõju etnograafilisele mõistmisele.

ERMi välitööde päevikute analüüs kinnitab osaliselt Lakoffi ja Johnsoni vaadet metafooride rollile mõtlemises. Kui etnograafid kasutavadki päevikutes kauplemise või saagiga seotud metafoore, ei pea see ilmtingimata kajastama sügavamaid mõtlemistasandeid, vaid võib olla ka spontaanne või ettekavatsetud sõnade mäng. Eesti etnograafide kogukonnas käibib teatud diskursuste stiil, mida siis teadvustamatult või teadlikult järgitakse. Samas, metafooride teadlik kasutamine ei välista iseenesest seda, et tegu on etnograafilise teadvuse süvatasanditega seotud diskursustega.

ART LEETE (PhD) on Tartu Ülikooli etnoloogia professor.

Ta on teinud välitöid Lääne-Siberis ja Komimaal. Tema uurimisteemad hõlmavad Siberi põlisrahvaste etnograafilise kirjeldamise ajalugu ja ühiskondlikke muutusi varasel nõukogude perioodil Lääne-Siberis, aga ka hantide, manside, neenetsite ja komide usundit ja jahipidamist.

PIRET KOOSA (PhD) on Eesti Rahva Muuseumi teadur. Tema 2017. aastal kaitstud doktoritöö käsitles postsotsialistliku perioodi usuelu Komimaal. Ta on teinud välitöid peamiselt Komimaal, aga ka Eestis ning Marimaal. Peamised uurimisteemad on seotud religiooni, soome-ugri kultuuride ja etnoloogia ajalooga.

\section{Allikad}

ERM A = Eesti Rahva Muuseumi arhiiv.

$\mathrm{TA}=$ Eesti Rahva Muuseumi topograafiline arhiiv:

TA 610. Karjala välitööd 1929.

TA 679. Komi välitööd 1976.

TA 681. Karjala välitööd 1976.

TA 692. Vadja välitööd 1976.

TA 719. Udmurdi välitööd 1978.

TA 742. Vadja välitööd 1979.

TA 746. Karjala välitööd 1979.

TA 748. Handi välitööd 1980.

TA 769. Vadja ja isuri välitööd 1982.

TA 776. Vepsa välitööd 1983.
TA 782. Mordva välitööd 1983.

TA 783. Udmurdi välitööd 1983.

TA 798. Mordva välitööd 1984.

TA 8o7. Mordva välitööd 1985.

TA 825. Isuri välitööd 1986.

TA 836. Vadja välitööd 1987 .

TA 837. Mordva ja mari välitööd 1987 .

TA 838. Mordva ja mari välitööd 1987.

TA 848. Handi välitööd 1988.

TA 852. Isuri välitööd 1988.

TA 858. Komi välitööd 1989. 


\section{Kirjandus}

Arukask, Madis. 2018. Soomeugrilusest eesti rahvuspildis - kas jagatud emotsioon või hägune küsitavus? - Keel ja Kirjandus 1-2: 104-117.

Atkinson, Paul. 1994 The Ethnographic Imagination. Textual Construction of Reality. London and New York: Routledge.

Biolsi, Thomas; Larry J. Zimmerman. 1997. Indians and Anthropologists: Vine Deloria, Jr. and the Critique of Anthropology. Tucson: University of Arizona Press.

Classen, Constance; David Howes. 2006. The museum as sensescape: Western sensibilities and indigenous artifacts. - Sensible Objects: Colonialism, Museums and Material Culture, ed. by Elizabeth Edwards, Chris Gosden, Ruth B. Phillips. London: Routledge, 199-222.

Clifford, James. 1986. On the ethnographic allegory. - Writing Culture: The Poetics and Politics of Ethnography, ed. by James Clifford and George E. Marcus. Berkeley, Los Angeles, London: University of California Press, 98-121.

Geertz, Clifford. 1997 [1988]. Works and Lives: The Anthropologist as Author. Stanford University Press.

Geertz, Clifford. 200o. Available Light: Anthropological Reflections on Philosophical Topics. Princeton, Oxford: Princeton University Press.

Jans, Johannes. 2006 [1920]. Johannes Jansi päevaraamat kogumisreisist Muhu saarele 1920. aastal. - Eesti Rahva Muuseumi aastaraamat XLIX: 221-263.

Jääts, Indrek; Marleen Metslaid. 2018. Eesti etnograafia ja eesti rahvuslus. - Keel ja Kirjandus 1-2: 118-135.

Jääts, Indrek. 2018. Eesti etnograafid lõunavepsa külades 1965-1969. - Eesti Rahva Muuseumi aastaraamat $61: 44^{-} 79$.

Jääts, Indrek. 2019a. Ekspeditsioonid läänemeresoome muinasmaale. Eesti etnograafide vepsa välitööde päevikud (1962-1969). Tartu: Eesti Rahva Muuseum.

Jääts, Indrek. 2019b. Soome-ugri suuna taassünd Eesti etnograafias. Uurimisretked vepsa küladesse aastail 1962-1969. - Ekspeditsioonid läänemeresoome muinasmaale. Eesti etnograa- fide vepsa välitööde päevikud (1962-1969), koost Indreks Jääts. Tartu: Eesti Rahva Muuseum, 15-53.

Karm, Svetlana. 2002. Eesti Rahva Muuseumi udmurdi kogud. - Eesti Rahva Muuseumi aastaraamat XLVI: 121-158.

Karm, Svetlana. 2006. Eesti etnoloogid Udmurtias. Eesti Rahva muuseumi 1971.-1991. aasta udmurdi ekspeditsioonide päevikute analüüs. - Eesti Rahva Muuseumi aastaraamat XLIX: 157-194.

Karm 2019 = Карм, Светлана. 2019. Финноугорский дискурс в эстонской этнологии (на примере исследования удмуртской культуры). Dissertationes Ethnologiae Universitatis Tartuensis 9. Tartu: University of Tartu Press.

Koosa, Piret; Art Leete. 2006. The ethnographer as a trader: On some metaphors in the Komi fieldwork diaries. - Sign Systems Studies 34 (2): $387-403$

Lakoff, George; Mark Johnson. 1999. Philosophy in the Flesh: The Embodied Mind and its Challenge to Western Thought. New York: Basic Books.

Lakoff, George; Mark Johnson. 2011. Metafoorid, mille järgi me elame. Tallinn: TLÜ Kirjastus.

Latkin 1844 = Латкин, Василий Николаевич. 1844. Заметки о самоедах. Санкт-Петербург.

Leete, Art. 1998a. Komi objects at the Estonian National Museum. - Procedural Work on Artefacts. Pro Ethnologia 6: 41-54.

Leete, Art. 1998b. Soome-ugri kultuuride etnoloogilise talletamise tänapäevaseid probleeme Eesti Rahva Muuseumis. - Eesti Rahva Muuseumi aastaraamat XLII: 11-33.

Linnus, Ferdinand. 1938. Die estnische Ethnographie in den letzten fünf Jahren. - Balticoslavica III: 128-135.

Linnus, Jüri. 197o. Eesti NSV Riikliku Etnograafiamuuseumi soome-ugri rahvaste etnograafilised kogud. - Läänemeresoomlaste rahvakultuurist, koost Jüri Linnus. Tallinn: Valgus, 226-246.

Linnus, Jüri. 1982. Liivi etnograafilise materjali kogumine Eestis. - Läänemeresoomlaste etnokultuuri küsimusi, koost ja toim Jüri Linnus. Tallinn: Valgus, $85-87$. 
Malinowski, Bronislaw. 2005 [1922]. Argonauts of the Western Pacific: An Account of Native Enterprise and Adventure in the Archipelagoes of Melanesian New Guinea. London: Routledge.

Marcus, George E. 1998. Ethnography through Thick and Thin. Princeton: Princeton University Press.

Marcus, George E.; Michael J. Fischer. 1999. Anthropology as Cultural Critique: An Experimental Moment in the Human Sciences. Chicago, London: The University of Chicago Press.

Nõmmela, Marleen. 2007a. Gustav Ränk 1928. aasta suvel Karjalas: etnograafilise praktika analüüs. - Eesti Rahva Muuseumi aastaraamat L: $43^{-7} 8$.

Nõmmela, Marleen. 2007b. Etnograafiks kujunemine: Gustav Ränga välitööpraktika 1920. aastatel. Studia Ethnologica et Folkloristica Tartuensia 10. Tartu: Tartu Ülikooli Kirjastus.

Peterson, Aleksei. 196o. Eesti NSV Teaduste Akadeemia Etnograafia Muuseum nõukogude võimu aastail. - Etnograafia Muuseumi aastaraamat XVII: 7-19.

Peterson, Aleksei. 1982. Vepslaste materiaalse kultuuri kogumisest ja uurimisest. - Läänemeresoomlaste etnokultuuri küsimusi, koost ja toim Jüri Linnus. Tallinn: Valgus, 5-7.

Peterson, Aleksei. 1986. Varaait: ülevaade etnograafiamuuseumi ajaloost ja kogudest. Tallinn: Valgus.

Peterson, Aleksei. 2006. Udmurdi päevikud. Удмуртъёс дорын чаклам-гожъямъёс. Tartu: Eesti Rahva Muuseum.

Pärdi, Heiki. 1982. Vadja aines Eesti NSV Riikliku Etnograafiamuuseumi kogudes. - Läänemeresoomlaste etnokultuuri küsimusi, koost ja toim Jüri Linnus. Tallinn: Valgus, 24-26.

Pärdi, Heiki. 1995a. „Argielu ja rahvakultuur”. Sajandialguse Saaremaa Eesti Rahva Muuseumi välipäevikuis. - Saaremaa Muuseum: kaheaastaraamat 1993-1994: 24-43.
Pärdi, Heiki. 1995b. Eesti etnoloogide aukartus elu ees. Välitööpäevikud kultuuriuurimise allikana. - Allikad ja Uurimused. Sources and Research. Pro Ethnologia 3: 67-86.

Reemann, Vaike. 1984. Karjala aines Eesti NSV Riikliku Etnograafiamuuseumi kogudes. Etnograafiamuuseumi aastaraamat XXXIV: 64-7o.

Rubel, Paula G. 2003. Traveling cultures and partial fictions: Anthropological metaphors for the new millennium? - Zeitschrift für Ethnologie $128(1): 3-24$.

Sevilla Casas, Elías. 2002. Metaphor, interpenetration and ethnography: a review essay with reflections on Northrop Frye's ideas. - Documentos de Trabajo. Santiago de Cali: Universidad del Valle, CIDSE. http://biblioteca.clacso.edu. ar/Colombia/cidse-univalle/20190607055140/ doc58.pdf (viimati külastatud 27.12.2020)

Sikka, Toivo. 1997. Eesti Rahva Muuseum ja soomeugri rahvad. Ülevaade kogudest, ekspeditsioonidest, konverentsidest ja näitustest. - Hõimusidemed. Fenno-Ugria 7o. aastapäeva album. URL: http://www.suri.ee/hs/ (viimati külastatud 9.02.2021)

Varvantakis, Christos; Sevasti-Melissa Nolas. 2019. Metaphors we experiment with in multimodal ethnography. - International Journal of Social Research Methodology 22 (4): 365-378. DOI: 10.108o/13645579.2019.1574953 
Art Leete

Piret Koosa

Our aim is to examine how the principles of museum collecting are reflected in ethnographic fieldwork diaries. In recent decades, scholars and representatives of indigenous peoples have sharply criticized earlier modes of ethnographic collection and representation. The earlier acquisition policy was based on the understanding that ethnographers had a kind of prerogative to collect objects and that people had to relinquish their possessions in the name of science. By now such collecting practices have changed, but the analysis of the ethnographers' earlier techniques enables us to gain a clearer sense of the historical context of museum collection.

In this article, we study various metaphors related to museum collecting that we found in Soviet-era FinnoUgric expedition diaries kept in the manuscript archive of the Estonian National Museum (ENM). We examine how the museum's ethnographers used specific metaphorical expressions and descriptive models. An exploration of diaries through metaphors offers a way to discuss the formation of ethnographic knowledge. Such an approach can be more subjective, but the metaphorical models that reappear in the field diaries do show that certain beliefs and the fundamental nature of their expression were more prevalent among the museum's staff.

We analyze the diaries of Finno-Ugric fieldwork kept from 1975 to 1989 , the most intensive period of the museum's collecting work among the Finno-Ugric peoples. The objects collected 
during these years make up almost two thirds of the current Finno-Ugric collection of the ENM.

The Finno-Ugric expedition diaries of the mature Soviet era reveal some metaphorical expressions and descriptions pertaining to museum collecting that are used repeatedly. We found that the metaphors of trade, war and loot characterized the era's collection practices in the most expressive way. These metaphors reflect, in the humorous and grotesque key, the ENM's staff's perceptions of time-specific museological principles. In their 1980 monograph "Metaphors We Live By", George Lakoff and Mark Johnson substantiated the universal potential of metaphor in human thought. While for Lakoff and Johnson, metaphor is a tool that enables us to talk about reality, what is more important is that metaphors serve as a meeting place of fundamental questions concerning people's everyday experience and life. The analysis of the ENM fieldwork diaries partially confirms Lakoff and Johnson's view. Although ethnographers use metaphors of trade, war and loot in their fieldwork diaries, they need not always be related to existential reflections, but are often just an entertaining play on words. At the same time, the playful use of metaphors does not in itself preclude the fact that they also reflect the discourses of the deep structure of ethnographic consciousness. 


\title{
Метафоры, которыми мы рабо- таем: отображение методики собирательской деятельности в дневниках финно-угорских экспедиций Эстонского нацио- нального музея 1975-1989 гг.
}

\author{
Арт Леэте \\ Пирет Кооса
}

Цель нашей работы - изучить отображение принципов собирательской работы музеев в дневниках этнографических полевых исследований. В последние десятилетия прежние этнографические методы собирания и репрезентации подвергались жёсткой критике со стороны учёных и представителей коренных народов. Раньше формирование музейных коллекций основывалось на убеждении, согласно которому, этнографы имеют полное право на собирание этнографических предметов, а население во имя науки должно отдавать им свои вещи. На сегодняшний день практика собирания изменилась, однако анализ прежних приёмов этнографов может помочь лучше понять исторический контекст формирования музейных собраний.

В статье рассматриваются связанные с собирательской работой метафоры из финно-угорских экспедиционных дневников советского времени, хранящихся в рукописном архиве Эстонского национального музея (ЭНМ). Анализу подвергается использование этнографами ЭНМ специфических метафорических выражений и описательных моделей. Изучение дневников посредством метафор - один из способов рассмотрения процесса формирования этнографического знания. Подобный подход, с 
одной стороны, субъективен, однако метафорические модели, неоднократно встречающиеся в полевых дневниках, показывают, что определённые убеждения и манера их выражения имели широкое бытование в коллективе ЭНМ.

В работе анализируются дневники финно-угорских полевых исследований 1975-1989 гг. В рассматриваемый период собирательская работа среди финно-угорских народов была наиболее интенсивной за всю историю музея. Экспонаты, накопленные в эти годы, составляют почти 2/3 нынешней финно-угорской коллекции ЭНМ.

В дневниках финноугорских экспедиций советского времени обнаруживаются повторяющиеся метафорические выражения, описывающие собирательскую работу. Наиболее выразительно собирательская деятельность этнографов того времени описывается метафорами о торговле, войне и добыче. В них в юмористическом и гротескном ключе отображаются представления тогдашних сотрудников ЭНМ о специфических музеологических принципах эпохи.

Универсальный потенциал метафоры в мышлении человека был обоснован Джорджем Лакоффом и Марком Джонсоном в монографии «Метафоры, которыми мы живём» (1980). По их мнению, метафора, с одной стороны, несомненно является средством описания действительности, однако важнее то, что метафоры функционируют в качестве места, в котором сходятся существенные вопросы, касающиеся повседневного опыта и жизни людей. Анализ дневников полевых исследований ЭНМ лишь частично подтверждает взгляды Дж. Лакоффа и М. Джонсона. Этнографы используют в своих дневниках метафоры о торговле, войне и добыче, но они не всегда связаны с размышлениями на существенные темы. Зачастую это просто увеселительная игра слов. Вместе с тем само по себе игровое использование метафор не исключает отображения в них глубинных дискурсов этнографического сознания. 